\title{
Kontinuerlig eller konstant?
}

Adjektivene kontinuerlig og konstant brukes ofte om hverandre. De har overlappende betydning, men bør brukes forskjellig.

Adjektivet kontinuerlig (lat. continuus) brukes ofte for å beskrive en tilstand eller virksomhet som vedvarer uten avbrudd $(1,2)$. Man leser for eksempel i pasientjournaler om pasienter med kontinuerlige smerter, med andre ord smerter uten avbrudd. Adjektivet konstant (lat. constans) beskriver i snever forstand en fysisk størrelse som ikke endrer verdi. I videre forstand er konstant synonymt med adjektivene varig eller ubrutt $(3,4)$. Med den sistnevnte betydningen er det ingen meningsbærende forskjell mellom adjektivene kontinuerlig og konstant. Dette er til hinder for språklig presisjon.

\section{a) Kontinuerlig og konstant}

Grad

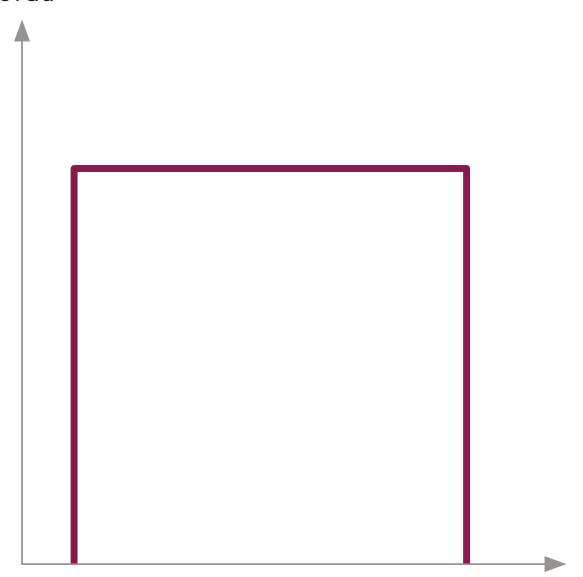

Tid

\section{Viktig å presisere}

Ukorrekt bruk og forståelse av disse adjektivene kan være potensielt villedende i legepasient-kommunikasjon og i pasientjournaler. Adjektivene brukes ofte for å beskrive en pasients symptomer, for eksempel smerter. For å unngå misforståelser mener vi kontinuerlig bør brukes når pasienten har smerter uten avbrudd, men som varierer $\mathrm{i}$ intensitet. For å unngå tvetydighet kan man benytte frasen «kontinuerlige, men ikke konstante, smerter». Konstant bør forbeholdes beskrivelser av smerter som både er uten avbrudd og som ikke varierer

b) Kontinuerlig, men ikke konstant

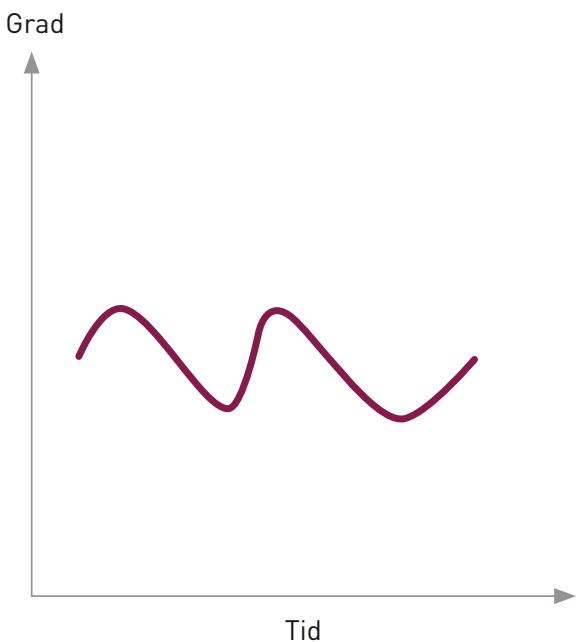

Figur 1 Grafisk fremstilling av begrepene kontinuerlig og konstant, som her representeres av henholdsvis $x$-aksen (tid) og $y$-aksen (grad) $\mathrm{i}$ intensitet. Figur 1 illustrerer at det strengt tatt ikke er mulig å betegne en tilstand som konstant uten at den samtidig er kontinuerlig. Derimot kan tilstanden være kontinuerlig uten å være konstant.

\section{Marius Kalsås Worren}

marius.worren@student.uib.no

Eirik Madsen

Bergen

Marius Kalsås Worren (f. 1988) er medisinstudent ved Universitetet i Bergen og har fra høsten 2008 fulgt forskerlinjeprogrammet ved Det medisinsk-odontologiske fakultet med et prosjekt om barn med AD/HD undersøkt ved EEG.

Eirik Madsen (f. 1987) er medisinstudent ved Universitetet i Bergen og har fra høsten 2008 fulgt forskerlinjeprogrammet ved Det medisinsk-odontologiske fakultet med et prosjekt om regulering av AMPA-reseptorer i netthinnen ved diabetes.

\section{Litteratur}

. Norsk ordbok. Kontinuerlig. http://ordnett.no/ search?search=kontinuerlig\&lang=no (7.3.2012).

2. Bokmålsordboka. Kontinuerlig. www.nob-ordbok. uio.no/perl/ordbok.cgi?OPP=kontinuerlig \& bokmaal=+\&ordbok=bokmaal (7.3.2012)

3. Norsk ordbok. Konstant. http://ordnett.no/ search?search=konstant\&lang=no (7.3.2012).

4. Bokmålsordboka. Konstant. www.nobordbok.uio.no/perl/ordbok.cgi?OPP= konstant \& bokmaal=+\&ordbok=bokmaal (7.3.2012).

Mottatt 7.3. 2012, første revisjon innsendt 10.4 . 2012, godkjent 15.4.2012. Medisinsk redaktør Raida Ødegaard. 